\title{
Androgens and Estrogens Synergistically Regulate the Expression of Doublecortin and Enhance Neuronal Recruitment in the Song System of Adult Female Canaries
}

\author{
Takashi Yamamura, ${ }^{1}$ Jennifer M. Barker, ${ }^{2}$ Jacques Balthazart, ${ }^{2}$ and Gregory F. Ball ${ }^{1}$ \\ ${ }^{1}$ Department of Psychological and Brain Sciences, Johns Hopkins University, Baltimore, Maryland 21218, and ${ }^{2}$ GIGA Neurosciences, University of Liège, \\ B-4000 Liège, Belgium
}

Vocal control nuclei in songbirds display seasonal changes in volume that are regulated by testosterone $(\mathrm{T})$ and its androgenic $(5 \alpha-$ dihydrotestosterone; DHT) or estrogenic ( $17 \beta$-estradiol; $\left.\mathrm{E}_{2}\right)$ metabolites. In male canaries, T regulates expression of the microtubuleassociated protein doublecortin (DCX), a marker of neurogenesis. We examined the effect of $\mathrm{T}$ and its two metabolites alone or in combination on DCX expression in adult female canaries. Treatment with T or with DHT $+\mathrm{E}_{2}$ increased HVC volume and neuron numbers as well as the total numbers of fusiform (migrating) and round (differentiating) DCX neurons in the nucleus but generally not in adjacent areas. DHT or $\mathrm{E}_{2}$ alone did not increase these measures but increased the density of fusiform DCX cells per section. Similar results were observed in area $\mathrm{X}$, although some effects did not reach significance, presumably because plasticity in $\mathrm{X}$ is mediated transsynaptically and follows HVC changes with some delay. There was no effect of any treatment on the total number of neurons in area X, and no change in DCX cell densities was detected in the lateral magnocellular nucleus of the anterior nidopallium, nor in other parts of the nidopallium. DHT and $\mathrm{E}_{2}$ by themselves thus increase density of DCX cells migrating through HVC but are not sufficient in isolation to induce the recruitment of these newborn neurons in the nucleus. These effects are generally not observed in the rest of the nidopallium, implying that steroids only act on the attraction and recruitment of new neurons in HVC without having any major effects on their production at the ventricle wall.

\section{Introduction}

In songbirds, nuclei that control song behavior, such as HVC, the robust nucleus of arcopallium (RA), and area $\mathrm{X}$, undergo dramatic seasonal changes in volume (Nottebohm, 1981). This plasticity in HVC is regulated, at least in part, by the direct action of gonadal testosterone (T) (Brenowitz, 2008), whereas the plasticity observed in RA and area $\mathrm{X}$ is primarily the result of T-driven changes in afferent inputs originating from HVC (Brenowitz and Lent, 2001, 2002). These volume changes result from a variety of effects on cellular processes and, for HVC specifically, from the incorporation and survival of newborn neurons (Alvarez-Buylla et al., 1990a,b; Nottebohm et al., 1994). Testosterone is readily metabolized to an androgenic metabolite, $5 \alpha$-dihydrotestosterone (DHT), by the enzyme $5 \alpha$-reductase, or to an estrogenic metabolite, $17 \beta$-estradiol $\left(\mathrm{E}_{2}\right)$, by the enzyme aromatase (Schlinger and Brenowitz, 2002). Both of these enzymes are present in the song-

Received Jan. 5, 2011; revised April 22, 2011; accepted May 13, 2011.

Author contributions: T.Y., J.B., and G.F.B. designed research; T.Y. and J.M.B. performed research; T.Y. and J.M.B. analyzed data; T.Y., J.B., and G.F.B. wrote the paper.

This study was supported by NIH Grant R01 NS35467 to G.F.B. J. Barker was supported by a University of Liège postdoctoral grant. We thank David Mehler for assistance with counting DCX-ir cell number.

Correspondence should be addressed to Gregory F. Ball, Department of Psychological and Brain Sciences, Johns Hopkins University, 3400 North Charles Street, Baltimore, MD 21218. E-mail: gball@jhu.edu.

T. Yamamura's present address: Laboratory of Neurobiology, National Institute of Agrobiological Sciences, 2-1-2 Kannondai, Tsukuba 305-8602, Japan.

DOI:10.1523/JNEUROSCI.0088-11.2011

Copyright $\odot 2011$ the authors $\quad 0270-6474 / 11 / 319649-09 \$ 15.00 / 0$ bird brain, and both androgen (Balthazart et al., 1992; Soma et al., 1999) and estrogen (Gahr et al., 1993; Bernard et al., 1999) receptors are located within HVC in canaries. Accordingly, metabolites of $\mathrm{T}$ often act synergistically to produce the effects observed after $\mathrm{T}$ administration (DeVoogd and Nottebohm, 1981).

Doublecortin (DCX) is a microtubule-associated protein expressed during development and adulthood in postmitotic migrating and differentiating neurons in mammals (Francis et al., 1999; Rao and Shetty, 2004). DCX mediates the growth of the leading process and stabilizes the cytoskeleton during neuronal migration, and thus is involved in the final positioning of newborn neurons (Friocourt et al., 2003). DCX has been found in HVC and area X of male canaries (Boseret et al., 2007; Balthazart et al., 2008), where it is coexpressed in $>70 \%$ of new (BrdUpositive) migrating neurons, consistent with it being a marker of neurogenesis (Balthazart et al., 2008). Within HVC, the number of DCX-immunoreactive (ir) cells is increased by treatment with $\mathrm{T}$ (Balthazart et al., 2008). An endogenous marker of neurogenesis such as DCX provides an integrated view of all new neurons present at a given location at a given time, while BrdU-positive cells provide a snapshot of a selection of these cells that were born at a specific time (i.e., within a few hours after injection of BrdU) (Packard et al., 1973; Miller and Nowakowski, 1988; Böswald et al., 1990).

We tested here whether the metabolites of testosterone (DHT and $\mathrm{E}_{2}$ ) are responsible for the changes in HVC volume and the associated changes in numbers of DCX-ir cells observed after 
testosterone administration. We demonstrate that although both DHT and $\mathrm{E}_{2}$ tend to attract DCX cells to HVC, the synergistic action of DHT and $\mathrm{E}_{2}$ is required for the incorporation of these cells and the concomitant increase in nucleus volume. This experiment also established that testosterone affects the numbers of DCX-ir cells specifically in HVC but not in adjacent areas. These findings provide strong support for the assertion that testosterone acts specifically on the recruitment and differentiation of new neurons in HVC without affecting their rate of production at the ventricular level.

\section{Materials and Methods}

Animals and housing. Adult female canaries (American Singer breed) were obtained from a local breeder near Baltimore during the winter. Before their arrival in the laboratory in early December, they had been exposed to the natural photoperiod, which included $<12 \mathrm{~h}$ of light per day for several months. We confirmed by laparotomy that all subjects had small regressed ovaries when they arrived in the laboratory. Birds were maintained in indoor aviaries with a maximum of five subjects per cage $(49 \times 95 \times 51 \mathrm{~cm})$ under short day conditions ( $11 \mathrm{~h}$ light: $13 \mathrm{~h}$ dark), with food and water available ad libitum. In this way, we maintained the birds in a photosensitive reproductive state normally observed in late winter to early spring (Nicholls et al., 1988). All experimental protocols were approved by and performed under the guidelines laid out by the Johns Hopkins University Animal Care and Use Committee.

Experimental treatments and brain processing. One week after their arrival in the laboratory, all birds were implanted subcutaneously with two SILASTIC capsules (Dow Corning; internal diameter $=0.76 \mathrm{~mm}$, external diameter $=1.65 \mathrm{~mm}$, length $=10 \mathrm{~mm}$ ) that had been washed in ethanol and soaked in $0.1 \mathrm{~m}$ PBS. Birds in the first treatment group each received two empty (control; Ctrl) implants $(n=7)$. Birds in the second, third, and fourth groups each received one control empty implant and a second implant filled with crystalline $\mathrm{T}(n=7)$, DHT $(n=6)$, or $\mathrm{E}_{2}(n=$ 6). A fifth group received one DHT implant and one $\mathrm{E}_{2}$ implant in combination $(n=6)$. The doses of hormone (length and diameter of implants) used were selected based on previous studies (Sartor et al., 2005). After recovering from implantation, all birds were replaced in their original indoor aviaries, five subjects per cage (one bird from each of the five treatments in each cage) under the same photoperiod as above (11 h light:13 h dark). After 3 weeks, all birds were anesthetized with secobarbital and perfused intracardially with $\sim 50 \mathrm{ml}$ of physiological saline, followed by $100 \mathrm{ml}$ of fixative (4\% paraformaldehyde and $0.1 \%$ glutaraldehyde in $0.1 \mathrm{~m}$ phosphate buffer at $\mathrm{pH} 7.4$ ). The ovary and oviduct of each bird were weighed at this time. After perfusion, each brain was removed from the skull, postfixed overnight in paraformaldehyde-glutaraldehyde fixative at $4^{\circ} \mathrm{C}$, and then cryoprotected in a solution of $30 \%$ sucrose in PBS. Brains were frozen on powdered dry ice and stored at $-80^{\circ} \mathrm{C}$.

Brains were cut in $40 \mu \mathrm{m}$ coronal sections on a cryostat from the level of area $\mathrm{X}$ to the locus ceruleus. Four series of alternate sections were collected as free-floating sections. One series was Nissl stained with thionin to measure the volume, cell number, cell density, and somatic area of song control nuclei and to count pyknotic (dying) cells. DCX was visualized by immunohistochemistry in another series.

The anatomical definitions of different brain areas adopted in this paper are based on two avian brain atlases [canary: Stokes et al. (1974); pigeon: Karten and Hodos (1967)] with additional anatomical information concerning auditory and song control areas based on other, more specialized publications (Bottjer et al., 1989, 2000; Vates et al., 1996; Mello et al., 1998). The anatomical nomenclature used here is based on the recommendations made by the Avian Brain Nomenclature Forum (Reiner et al., 2004).

Volume of the song control nuclei. All Nissl-stained sections containing the song control nuclei HVC, RA, or area X were identified and digitized using a bright-field light microscope (Zeiss Axioskop, Carl Zeiss) with a CCD camera connected to a Macintosh computer. The area of each nucleus was traced in these digitized images on both sides of the brain and measured using Openlab 5.0.1 (Improvision). The volume of each
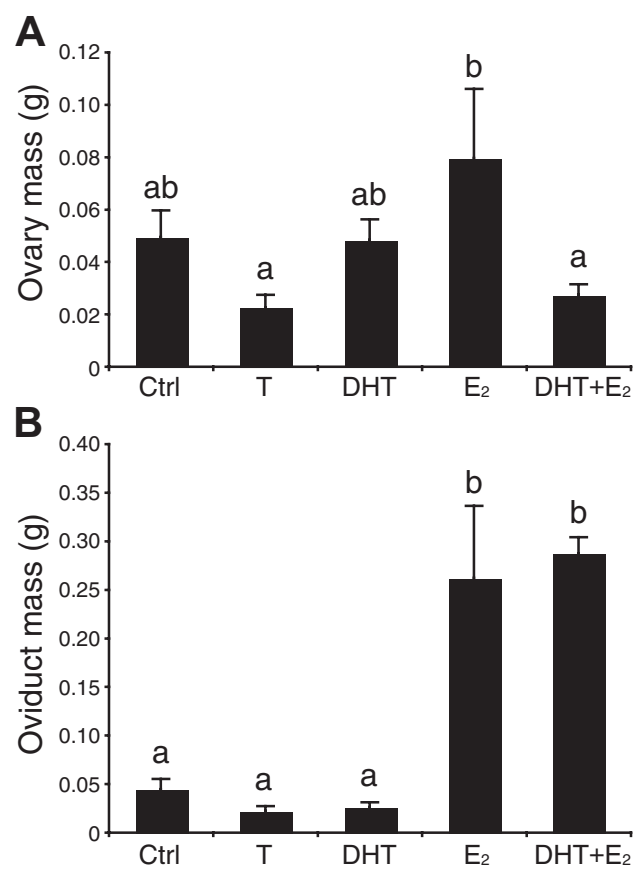

Figure 1. Effects of $\mathrm{T}$ and its androgenic (DHT) or estrogenic $\left(\mathrm{E}_{2}\right)$ metabolites alone or in combination on ovarian $(\boldsymbol{A})$ and oviduct $(\boldsymbol{B})$ mass in female canaries maintained on short days. Data were analyzed by one-way ANOVAs followed by Fisher's LSD post hoc tests (letters above the bars). Bars with different letters are significantly different for $p<0.05$ in $\boldsymbol{A}$ and for $p<$ 0.001 in $B$.

region was then reconstructed combining the areas of subsequent sections with the sampling interval $(160 \mu \mathrm{m})$ using the formula for a truncated cone (developed by Smith et al., 1995). For each bird, we used the average volume of the left and right hemispheres, summed the values across sections, and then multiplied by the interval between sections. HVC volumes was restricted to the nucleus itself and did not include the para-HVC (see Sartor and Ball, 2005).

Number, density, and soma size of cell in the song control nuclei. Neuron numbers and densities were estimated with the help of a random, systematic sampling protocol that has been previously described and validated for the canary brain that yields estimates in agreement with the stereological optical dissector method (Tramontin et al., 1998). Briefly, to choose visual fields to be sampled, a mapping grid was overlaid on the digitized images of brain nuclei that were investigated. Several randomly chosen visual fields were selected at $100 \times$ magnification to estimate the number of neurons that would be present in any given counting frame. This gave an estimate of how many frames were required to achieve a minimum sample (at least 140 neurons with 30-40 neurons per counting frame). The soma size of neurons was then measured using ImageJ software (version $1.40 \mathrm{~g}$ ) by tracing the cell edges in digitized images.

Neurons were manually counted using the Cell Counter function of ImageJ software (version $1.40 \mathrm{~g}$ ). Cells with one or two round nucleoli, a well defined nuclear envelope, nongranular cytoplasm, and/or an obvious axonal hillock were judged to be neurons (Tramontin et al., 1998). Neurons containing two nucleoli were always counted as one cell. Nucleoli that were bisected by either the left or the upper boundary of the counting frame were counted, whereas those that were bisected by the right or the lower boundary were not counted.

We counted putative neuronal nucleoli in randomly selected fields and used the following equation to estimate neuron density from these nonstereological counts: Density $=[n /(a \times T) g] \times 10^{9} \mu \mathrm{m}^{3} / \mathrm{mm}^{3}$, where $n=$ the number of neuronal nucleoli sampled, $a=$ grid square area, $T=$ section thickness $(40 \mu \mathrm{m})$, and $g=$ the number of grid squares sampled. We estimated neuron number by multiplying neuron density by total nucleus volume. We sampled at least 140 HVC neurons and 140 area X neurons per bird in fields randomly chosen in sections throughout the 
A

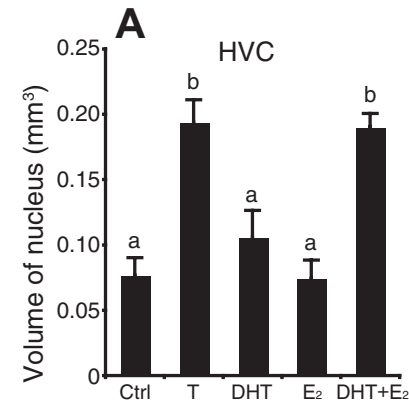

B

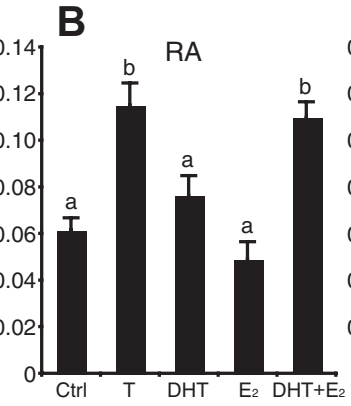

C

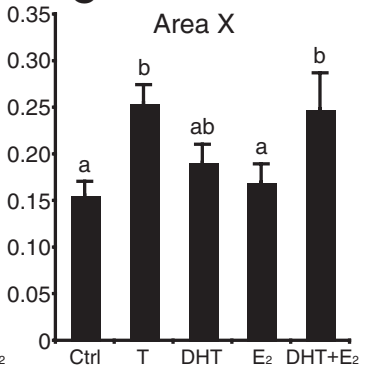

Figure 2. Tor a combination of its androgenic (DHT) and estrogenic $\left(E_{2}\right)$ metabolites increased the volume of HVC $(A)$, RA $(\boldsymbol{B})$, and area $\mathrm{X}(\boldsymbol{C})$ in female canaries. Data for each nucleus were analyzed by one-way ANOVAs followed by Fisher's LSD post hoc tests (letters above the bars). Bars with different letters are significantly different for $p<0.01$ in HVC and for $p<$ 0.05 in RA and area $X$.

A

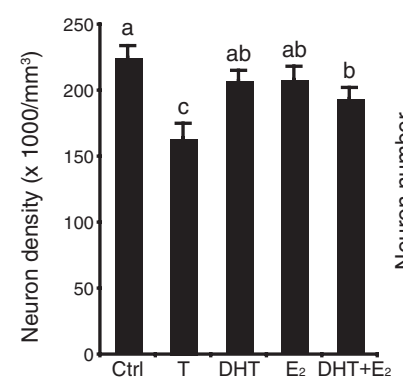

B

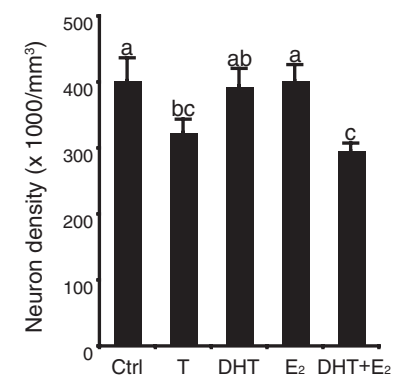

HVC

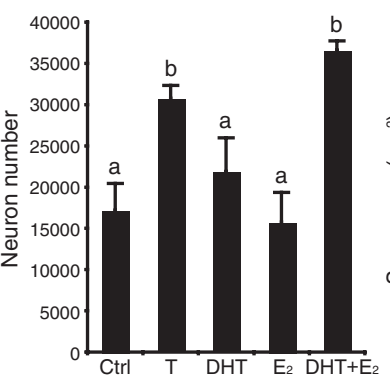

Area $\mathrm{X}$

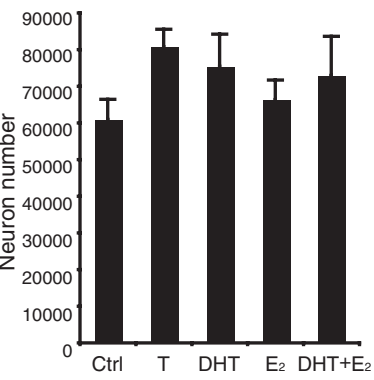

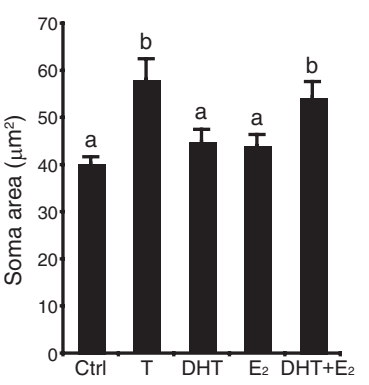

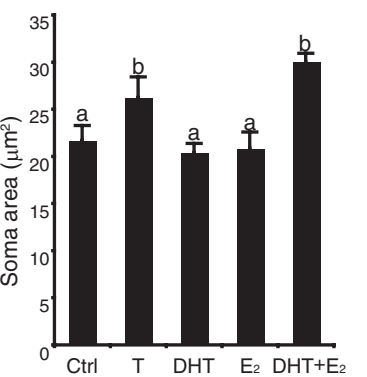

Figure 3. T or a combination of its androgenic (DHT) and estrogenic $\left(E_{2}\right)$ metabolites decreased neuron density (left) and increased estimates of neuron number (middle) and neuronal soma size (right) in $\mathrm{HVC}(\boldsymbol{A})$ and area $X(\boldsymbol{B})$. Bars with different letters are significantly different for $p<0.05$ as demonstrated by post hoc tests following a significant ANOVA.

rostral-caudal extent of each nucleus. Based on the work of Tramontin et al. (1998) comparing this method with a stereological approach, this sample size is sufficient to encompass the entire range of variability in neuron density and somatic area (also measured during this process) in these nuclei. All measurements were made blind to the steroid treatments for each bird.

DCX immunocytochemistry. Another series of sections was stained by immunocytochemistry for DCX. DCX is a protein expressed in new neurons (Francis et al., 1999; Rao and Shetty, 2004) that plays a critical role in the polymerization of microtubules and thus in neuronal migration. In both mammals and birds (Brown et al., 2003; Rao and Shetty, 2004; Balthazart et al., 2008; LaDage et al., 2010), the protein is expressed for a duration of 20-30 d after the final mitotic division. In canaries specifically, 70\% of DCX-ir fusiform cells have a nucleus marked with the thymidine analog bromo-deoxyuridine (BrdU) $10 \mathrm{~d}$ after its injection, but this number drops to $\sim 5 \%$ after $30 \mathrm{~d}$. These data thus suggest that new neurons express this protein for $\sim 1$ month, a period during which new neurons migrate to their final destination and begin their morphological differentiation.

Free-floating sections were immersed in a solution of $0.6 \% \mathrm{H}_{2} \mathrm{O}_{2}$ in $\mathrm{PBS}$ to block endogenous peroxidases for $20 \mathrm{~min}$. Sections were incu- bated in $10 \%$ normal horse serum (S-2000; Vector Laboratories) in PBS for $30 \mathrm{~min}$ at room temperature, followed by incubation with a primary antibody raised against DCX in goat (sc-8066, Santa Cruz Biotechnology; 1:200 in PBS) at $4^{\circ} \mathrm{C}$ for $72 \mathrm{~h}$. The specificity of this antibody was previously validated for DCX identification in canaries (Boseret et al., 2007; Balthazart et al., 2008). Sections were then treated with a secondary biotinylated anti-goat IgG antibody (BA-9500, Vector Laboratories; 1:200 in PBS) for $1 \mathrm{~h}$ at room temperature and with avidin-biotinylated peroxidase complex (Vectastain Elite ABC, PK-6100, Vector Laboratories; diluted in PBS as per the manufacturer's instructions) for $1 \mathrm{~h}$ at room temperature. The peroxidase activity was identified with a solution of 3,3-diaminobenzidine (D-4293, Sigma-Aldrich; $0.7 \mathrm{mg} / \mathrm{ml}$ in PBS). After each step, sections were carefully rinsed in $0.1 \mathrm{M}$ PBS containing $0.3 \%$ Triton X-100, except before the incubations in normal serum and primary antibodies. Sections were finally mounted in Permount (Fisher Scientific) on glass slides (Superfrost) and coverslipped.

Quantitative analysis of DCX labeling. The number of DCX-ir cells was counted in three song control regions (HVC, area $\mathrm{X}$, and the lateral magnocellular nucleus of the anterior nidopallium, LMAN), in areas adjacent to each of these nuclei and in ventral nidopallium, where cells expressing DCX have been previously reported in male canaries (Boseret et al., 2007; Balthazart et al., 2008). We focused on these nuclei because new neurons are not incorporated into RA and accordingly no DCX-ir cells are present in this nucleus. Specifically, in each bird DCX-ir cells were counted in three sections that included HVC, within three separate fields positioned in the center of HVC and in the immediately adjacent nidopallium just lateral and ventral to HVC (lat. to HVC; ventr. to HVC). DCX-ir cells were also quantified at two rostrocaudal levels in area X and in two regions adjacent (lateral and ventral) to area $\mathrm{X}$ (lat. to $\mathrm{X}$ and ventr. to $\mathrm{X}$ ), at one rostrocaudal level in LMAN and in one adjacent region (lateral) to LMAN (lat. to LMAN), and at three different rostrocaudal levels in three distinct zones (medial, lateral, and ventral) of the nidopallium (med. Nido; lat. Nido; ventr. Nido). We used the same quantification procedures as is described in detail in our previous studies (Boseret et al., 2007; Balthazart et al., 2008) and in particular the counting areas were placed at the exact same anatomical locations as described in Figure 1 of Balthazart et al. (2008).

Similar to what we reported in our previous studies of male canaries, two different types of DCX-ir cells (fusiform and round) were detected in the telencephalon (Boseret et al., 2007; Balthazart et al., 2008), and these two cell types were counted separately. For each area investigated, immunoreactive cells were manually counted on images digitized through the microscope $(20 \times$ objective $)$ in a standardized square area $(200 \times 200$ $\mu \mathrm{m})$ located within the area of interest. The Cell Counter function of ImageJ software (version 1.40g; Wayne Rasband, National Institutes of Health) was used to accumulate in a reliable manner data concerning the two cell types that can only be consistently recognized by a human eye. The area used for quantification was positioned within the structure of interest in a standard manner using clearly defined brain landmarks as previously described in detail (Balthazart et al., 2008) and all immunoreactive cells that contained a clear unstained nucleus surrounded by 
stained cytoplasm were manually labeled using different colors for round and fusiform cells. Cells were counted on one side of the brain that was randomly chosen.

The total numbers of DCX-ir cells present in the entire HVC and area $\mathrm{X}$ were calculated based on estimates of DCX-ir cell densities and of the total volume of these nuclei. All measurements were made by an observer (T.Y.) who was blind to the steroid treatments for each bird.

Pyknotic cell counts. To determine any effects of testosterone or its metabolites on cell death, pyknotic cells were counted in HVC, area X, and adjacent areas in Nissl-stained sections. Cells were considered to exhibit a pyknotic morphology if they contained darkly stained, condensed chromatin, with cytoplasm that was pale or absent. Cells were counted on both sides of the brain using a light microscope under $625 \times$ total magnification in a standardized square area $(200 \times 200 \mu \mathrm{m})$ located within each area of interest. The area used for quantification was positioned within the structure of interest in a standard manner using clearly defined brain landmarks. Pyknotic cells were counted at three rostrocaudal levels, in the center of HVC and in the immediately adjacent nidopallium just lateral and ventral to HVC (lat. to HVC; ventr. to HVC). Cells were also counted at two rostrocaudal levels in area X and in two adjacent regions lateral and ventral to area $\mathrm{X}$ (lat. to $\mathrm{X}$; ventr. to $\mathrm{X}$ ). We used the same quantification procedures as for counting DCX-ir cells (see above). These procedures are described in full detail in our previous studies (Boseret et al., 2007; Balthazart et al., 2008); the counting areas were placed at the exact same anatomical locations as described in Figure 1 of Balthazart et al. (2008). The total numbers of pyknotic cells in the entire HVC and area X were calculated based on these estimates of local density and the volume of the nuclei calculated above.

Statistical analyses. One-way ANOVAs were used to compare results across the different experimental treatments. These analyses were followed when appropriate by Fisher's least significant difference (LSD) post hoc tests. Numbers of pyknotic cells were not normally distributed and were thus compared with the nonparametric Kruskal-Wallis ANOVA. An effect was considered to be statistically significant when $p<0.05$. All data are presented as means \pm SEM

\section{Results}

\section{Ovary and oviduct growth}

Steroid hormone treatments significantly affected ovarian mass $\left(F_{(4,27)}=3.02, p=0.04\right)$ (Fig. $\left.1 A\right)$ as well as oviduct mass $\left(F_{(4,27)}=\right.$ $16.80, p<0.001$ ) (Fig. $1 B$ ) in these female canaries maintained under nonstimulatory short days. The two androgens ( $\mathrm{T}$ and DHT) numerically decreased the oviduct mass and T decreased ovarian mass, but these effects did not reach statistical significance. In comparison with the control condition, $\mathrm{E}_{2}$ tended to increase both of these measures, but the difference from control birds was significant $(p<0.05)$ only for oviduct mass. Post hoc tests also confirmed that birds treated with $\mathrm{E}_{2}$ had significantly larger ovaries than those treated with $\mathrm{T}$ or $\mathrm{DHT}+\mathrm{E}_{2}$. Birds treated with $\mathrm{DHT}+\mathrm{E}_{2}$, like $\mathrm{E}_{2}$-treated birds, had heavier oviducts than birds that received T, DHT alone, or empty capsules (Fig. $1 B)(p<0.05)$, but the addition of DHT to the $\mathrm{E}_{2}$ treatment decreased ovarian mass in a statistically similar manner as compared to birds treated with $\mathrm{E}_{2}$ alone.

\section{Volume of song control nuclei}

The different steroid hormone treatments significantly affected the volume of song control nuclei in intact female canaries (Fig. 2) (HVC: $F_{(4,27)}=15.04, p<0.001$; RA: $F_{(4,27)}=14.83, p<0.001$; area $\mathrm{X}: F_{(4,27)}=$

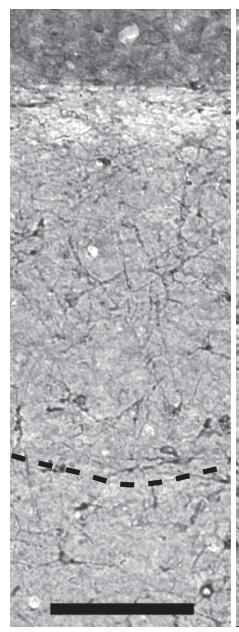

Ctrl

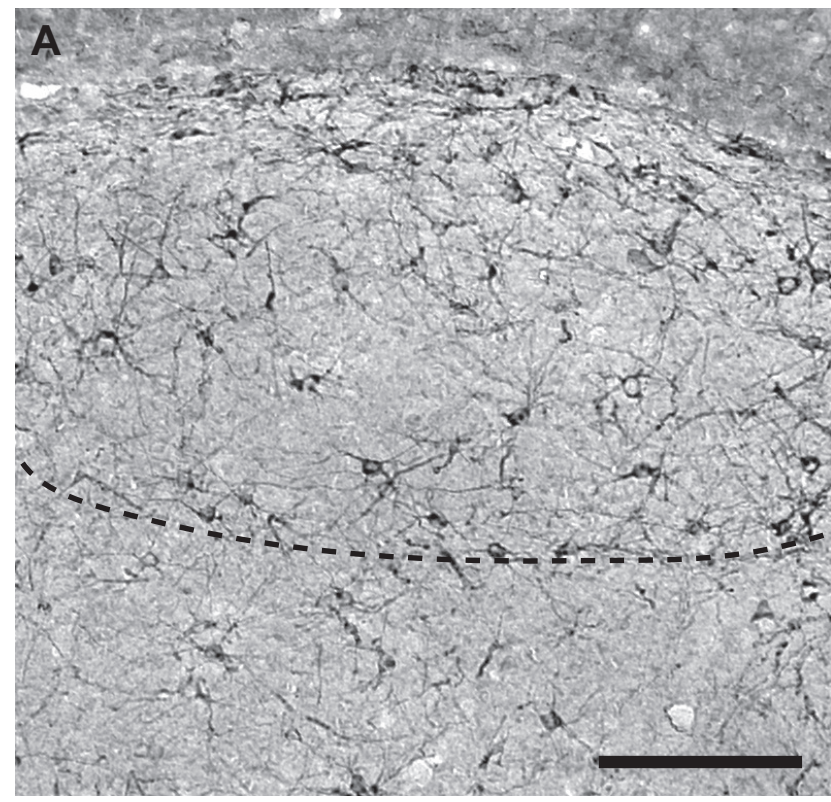

B

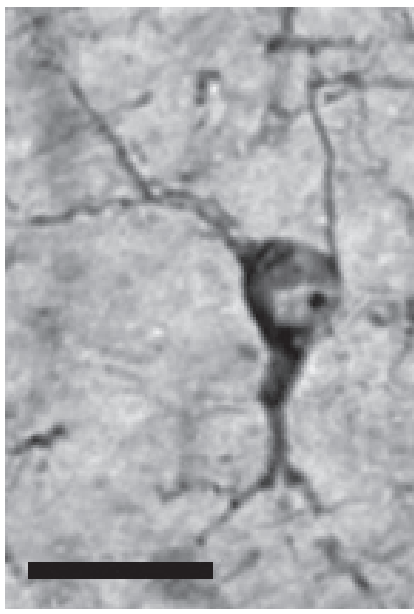

C

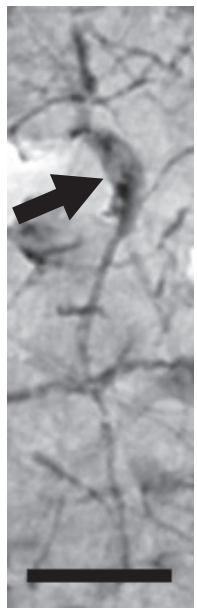

Figure 4. Photomicrographs illustrating the morphology of the round multipolar and fusiform DCX-ir cells that were identified and counted in the canary telencephalon. $A$, General view of HVC illustrating the high density of round and fusiform DCX-ir cells in the nucleus. The ventral edge of HVC is outlined by the dotted line. $B, C$, High-magnification enlargement of multipolar round DCX-ir cells (B) and one unipolar fusiform DCX-ir cells (C). Scale bars: $A, 250 \mu \mathrm{m} ; \boldsymbol{B}, \boldsymbol{C}, 20 \mu \mathrm{m}$.

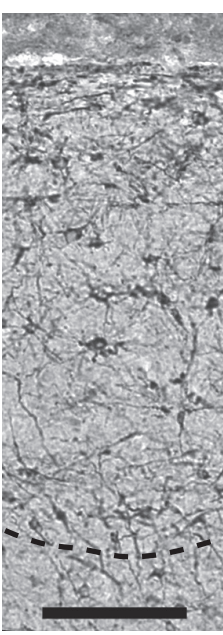

$\mathrm{T}$

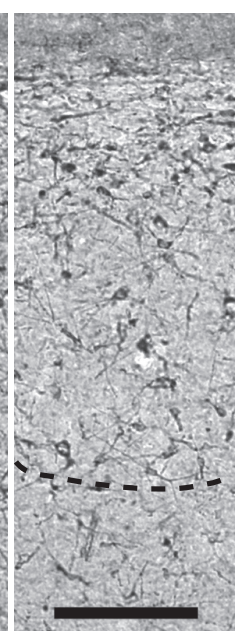

DHT

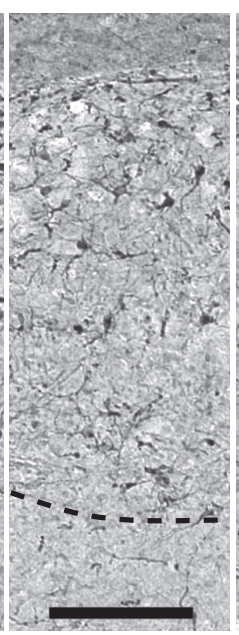

$\mathrm{E}_{2}$

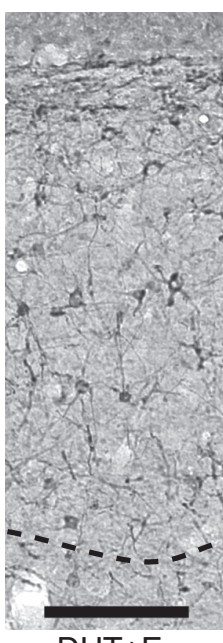

$\mathrm{DHT}+\mathrm{E}_{2}$
Figure 5. Photomicrographs of DCX-ir cells in HVC illustrating the changes in density of these cells in female canaries treated with different steroid hormones. The dotted lines indicate the ventral boundary of the nucleus. Scale bar, $125 \mu \mathrm{m}$. 

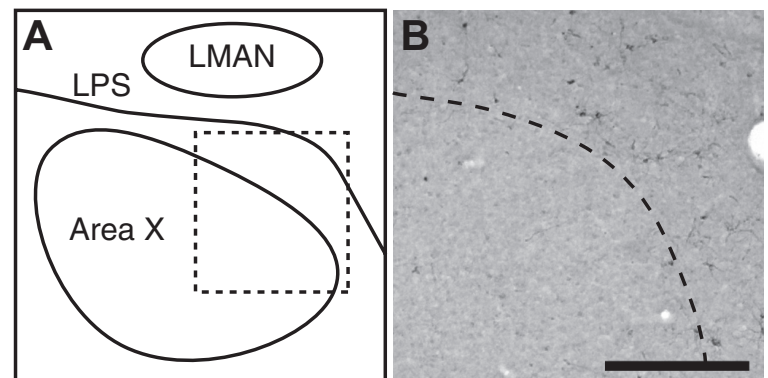

Ctrl

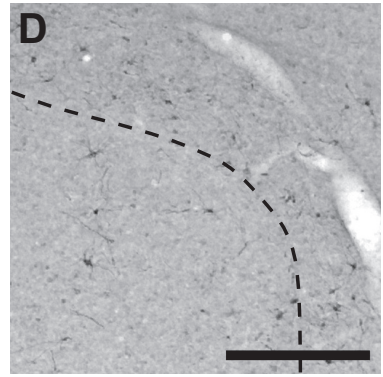

DHT

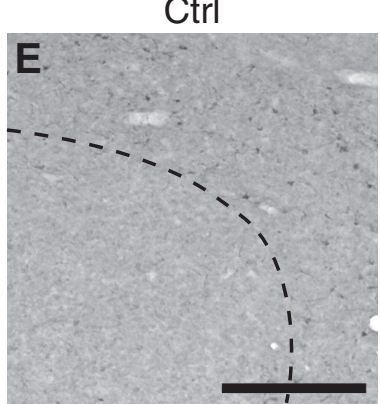

$\mathrm{E}_{2}$
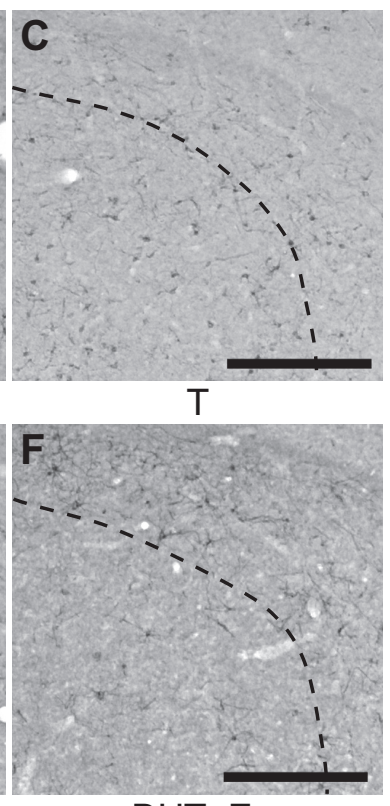

$\mathrm{DHT}+\mathrm{E}_{2}$

Figure 6. Photomicrographs of DCX-ir cells in area Xillustrating the changes in density of these cells in female canaries treated with various steroid hormones. $A$, Simplified schematic drawing of a coronal section at the level of area $X$ in the medial striatum indicating the areas illustrated in the photomicrographs (dotted square). $\boldsymbol{B}-\boldsymbol{F}$, Photomicrographs of DCX-ir cells in area X for each steroid hormone treatment. The dotted lines in $\boldsymbol{B}-\boldsymbol{F}$ indicate the dorsolateral boundary of area $X$. Note the much lower density of DCX-ir cells in area X than in HVC. LPS, Lamina palliosubpallialis. Scale bar, $250 \mu \mathrm{m}$.
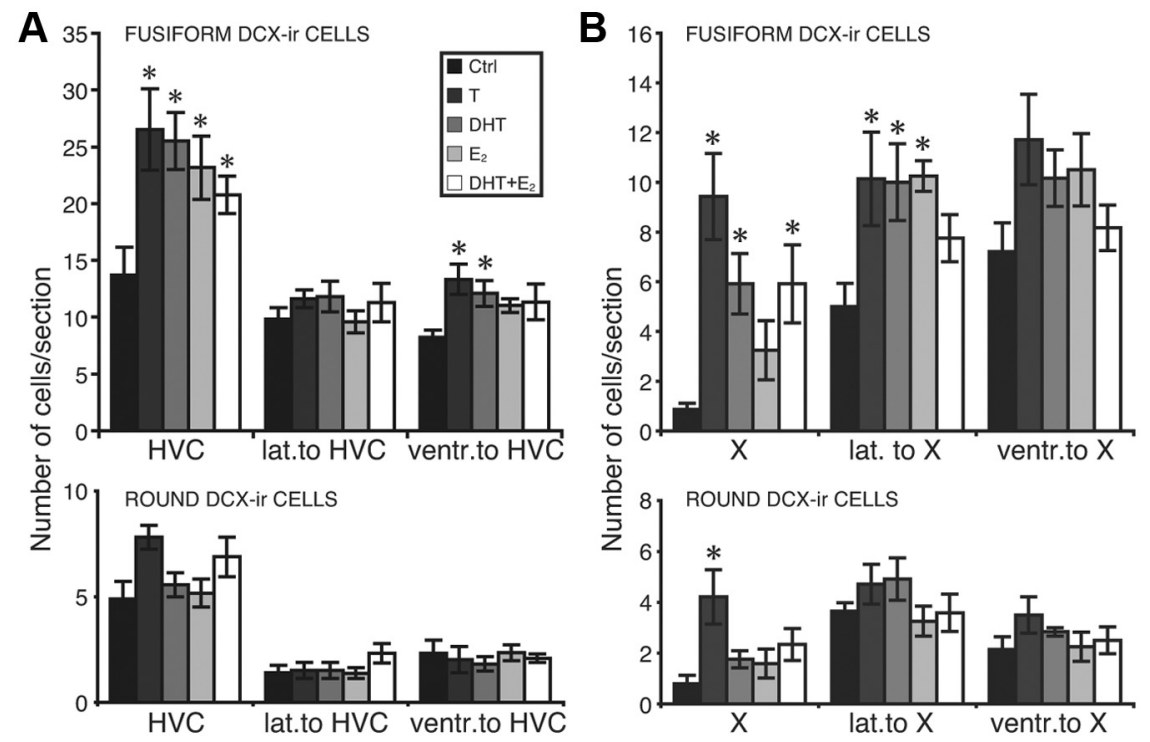

Figure 7. Numbers of DCX-ir cells counted in $\operatorname{HVC}(\boldsymbol{A})$ and area $X(\boldsymbol{B})$ and in adjacent areas just lateral and ventral to these nuclei. Results for fusiform (top) and round (bottom) cells are presented separately. ${ }^{*} p<0.05$ compared with controls.

cellular bases of the differential growth of song control nuclei in response to steroid treatments. The experimental treatments significantly affected neuron density $\left(F_{(4,27)}=6.26, p<0.001\right)$, the total number of neurons $\left(F_{(4,27)}=9.34, p<0.001\right)$, and the neuron soma area $\left(F_{(4,27)}=6.54\right.$, $p<0.001)$ in HVC (Fig. 3A). Treatments also affected neuron density $\left(F_{(4,27)}=\right.$ 3.91, $p<0.02)$ and neuronal soma area $\left(F_{(4,27)}=6.45, p<0.001\right)$ in area $\mathrm{X}$, but the total number of neurons present in this nucleus was not significantly affected $\left(F_{(4,27)}=1.27, p=0.31\right)$ (Fig. $\left.3 B\right)$.

Post hoc tests indicated that in HVC, neuronal density was decreased by $\mathrm{T}$ or $\mathrm{DHT}+\mathrm{E}_{2}(p<0.05)$, while total numbers of neurons and neuron soma area were increased by these two treatments $(p<$ $0.05)$. The same effects were observed in area $\mathrm{X}$ for neuronal density and neuronal soma areas (respectively decreased and increased following treatment with $\mathrm{T}$ or with $\left.\mathrm{DHT}+\mathrm{E}_{2} ; p<0.05\right)$. In both nuclei, DHT or $\mathrm{E}_{2}$ alone did not significantly affect any of these measures as compared to control birds receiving no steroid treatment (Fig. 3).

\section{DCX expression}

As observed in our previous studies on male canaries (Boseret et al., 2007; Balthazart et al., 2008), densely stained DCX-ir cells were observed throughout the telencephalon in female canaries, except in most of the arcopallium including nucleus RA. Two types of cells were observed in all these locations: round multipolar cells and fusiform unipolar or bipolar cells. These two cell types are illustrated for HVC in the photomicrographs presented in Figure 4.

The density of these DCX-ir cells was obviously affected by steroid treatments in both HVC and area X as illustrated by representative photomicrographs shown in Figures 5 and 6.

The numbers of fusiform and round DCX-ir cells were systematically counted in three song control nuclei (HVC, area X, and LMAN) and adjacent areas as well as in three locations within the nidopallium,

3.96, $p<0.05)$. Post hoc tests revealed that, as expected, T treatment induced the growth of these song control nuclei $(p<0.05)$. Similarly, the combined treatment with $\mathrm{DHT}$ and $\mathrm{E}_{2}$ increased the growth of all three song control nuclei in comparison with the control treatment $(p<0.05)$. In contrast, treatment with $\mathrm{DHT}$ or $\mathrm{E}_{2}$ alone was not effective in increasing the volume of song control nuclei above the volume measured in control birds $(p>0.05)$.

\section{Neuron numbers and size in HVC and area $\mathrm{X}$}

The neuron density, total number of neurons, and neuronal soma size were examined in HVC and area X to investigate the and these data were analyzed by one-way ANOVA. Steroid hormone treatments significantly affected the density of fusiform DCX-ir cells in $\operatorname{HVC}\left(F_{(4,27)}=6.15, p<0.001\right)$ and to a lesser extent in the area ventral to $\operatorname{HVC}\left(F_{(4,27)}=3.16, p=0.03\right)$ (Fig. $7 A)$. However, no treatment effects were present in the area just lateral to $\operatorname{HVC}\left(F_{(4,27)}=0.79, p=0.54\right)$. Post hoc tests indicated that the density of fusiform DCX-ir cells in HVC was significantly increased by all steroid treatments compared to control birds $(p<0.05)$. In addition, treatment with T or DHT alone increased the density of fusiform cells in the area ventral to HVC compared to control birds $(p<0.05)$. In contrast, the density of 


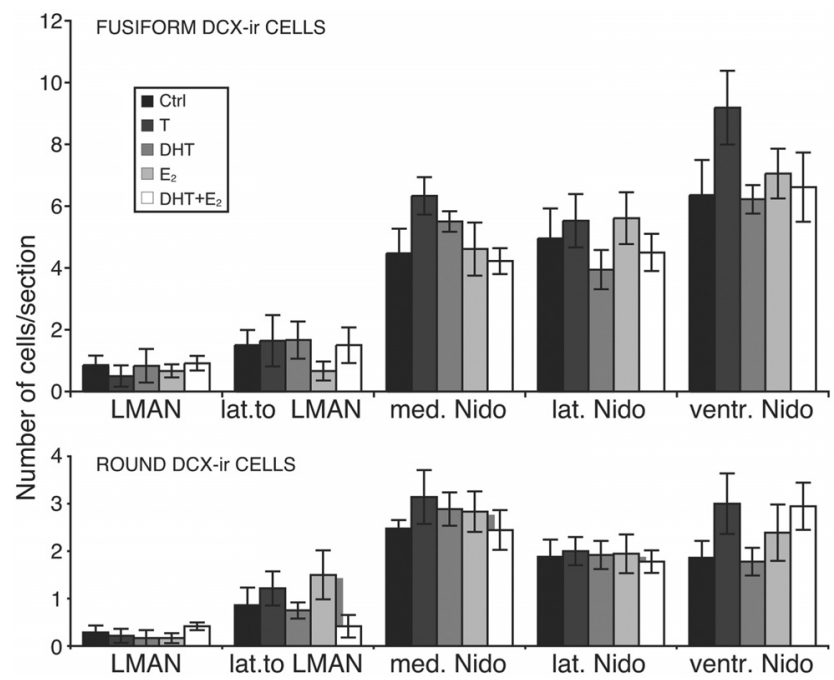

Figure 8. Numbers of DCX-ir cells counted in LMAN, the area directly lateral to LMAN, and in three parts of the nidopallium (medial, lateral, and ventral). Results for fusiform (top) and round (bottom) cells are presented separately.

round DCX-ir cells was not affected by steroid treatments in $\operatorname{HVC}\left(F_{(4,27)}=1.97, p=0.13\right)$, nor in the adjacent areas just lateral $\left(F_{(4,27)}=1.04, p=0.41\right)$ or ventral $\left(F_{(4,27)}=0.21, p=\right.$ 0.93 ) to this nucleus.

The experimental treatments also affected the density of fusiform DCX-ir cells in area $\mathrm{X}\left(F_{(4,27)}=6.64, p<0.001\right)$ and in the region immediately lateral to area $X\left(F_{(4,27)}=3.96, p<0.02\right)$ (Fig. $7 B$ ). Although a similar pattern of results was seen just ventral to area $\mathrm{X}$, differences between groups did not reach statistical significance $\left(F_{(4,27)}=1.89, p=0.14\right)$. In area $\mathrm{X}$, all androgenic treatments $\left(\mathrm{T}, \mathrm{DHT}\right.$, or $\left.\mathrm{DHT}+\mathrm{E}_{2}\right)$ but not $\mathrm{E}_{2}$ alone caused a marked increase in the density of fusiform DCX-ir cells as compared to control birds ( $p<0.05$ ). The density of fusiform DCX-ir cells lateral to area $\mathrm{X}$ was significantly increased by all steroid treatments except $\mathrm{DHT}+\mathrm{E}_{2}$.

The density of round DCX-ir cells was affected by steroid treatments in area $\mathrm{X}\left(F_{(4,27)}=3.19, p<0.03\right)$ (Fig. $\left.7 B\right)$ but not in adjacent areas. The significant effect observed within area $\mathrm{X}$ resulted exclusively from a T-induced increase $(p<0.05$ by post hoc test); treatments with DHT or $\mathrm{E}_{2}$ alone or in combination had no detectable effect.

No significant effect of the steroid hormone treatments on the density of fusiform or round DCX-ir cells was detected in or around LMAN or in the three parts of the ventral nidopallium that were sampled (all $p>0.14$ ) (Fig. 8).

\section{Pyknotic cell counts}

Pyknotic cells displaying darkly stained condensed nuclei (Fig. 9) were counted in and around HVC and area X. Pyknotic cell counts were extremely skewed, with large numbers of zeros in several areas. These data were therefore analyzed with the nonparametric Kruskal-Wallis ANOVA. These analyses revealed no significant effect of the experimental treatments on the density of pyknotic cells in HVC, area $\mathrm{X}$ or the adjacent regions examined (Fig. 10) $(p>0.35$ in all brain regions except in the area ventral to HVC where $p=0.09$ ).

\section{Total numbers of DCX-ir and pyknotic cells in HVC and} area $\mathrm{X}$

The total numbers of fusiform or round DCX-ir cells and of pyknotic cells in the entire HVC and area X were calculated based on the

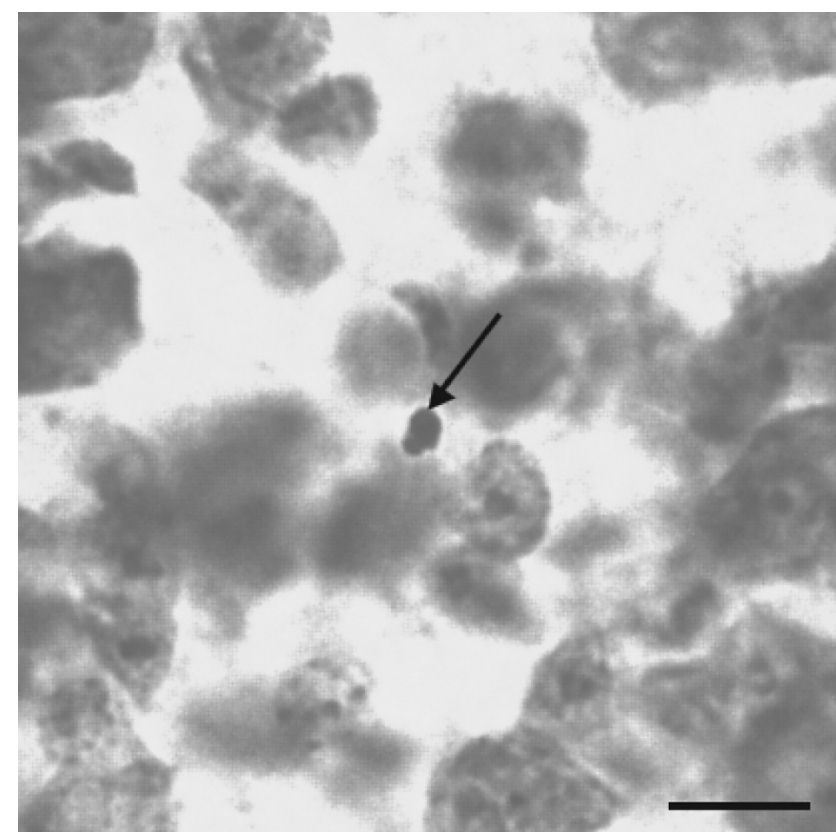

Figure 9. Photomicrograph illustrating the morphology of a pyknotic cell (arrow) with fragmented dark inclusions in the canary telencephalon. Scale bar, $10 \mu \mathrm{m}$.

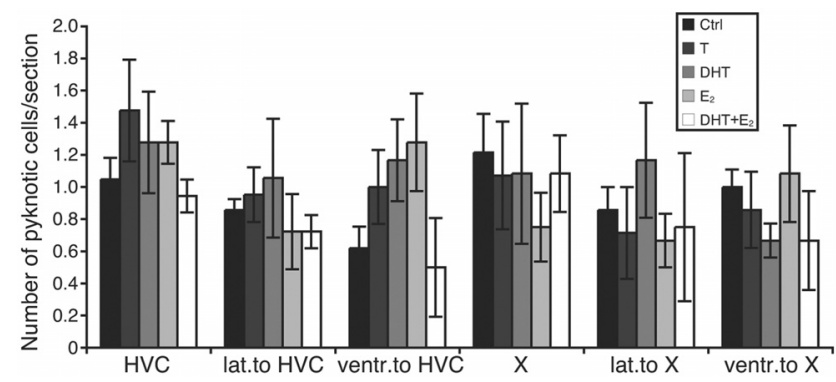

Figure 10. Numbers of pyknotic cells counted in HVC and area X and in the area just lateral or ventral to these nuclei.

estimates of their density in the sampled areas and on the volume of these nuclei. In HVC, steroid hormone treatments affected the total numbers of fusiform $\left(F_{(4,27)}=14.90, p<0.001\right)$ (Fig. 11A) and round DCX-ir cells $\left(F_{(4,27)}=7.23, p<0.001\right)$ (Fig. $\left.11 B\right)$ as well as the total number of pyknotic cells $\left(F_{(4,27)}=5.15, p<0.01\right)$ (Fig. $11 C)$. Post hoc tests showed that treatment with $\mathrm{T}$ or with $\mathrm{DHT}+\mathrm{E}_{2}$ increased the number of fusiform and of round DCX-ir cells whereas pyknotic cells numbers were increased only following treatment with $\mathrm{T}$ (see detail of these tests in Fig. 11). These effects are similar to, and partly the result of, the changes observed in volume of the nucleus.

In area $\mathrm{X}$, steroid hormone treatments affected the total numbers of fusiform $\left(F_{(4,27)}=5.45, p<0.01\right)$ (Fig. 11A) and round DCX-ir cells $\left(F_{(4,27)}=9.38, p<0.001\right)($ Fig. $11 B)$ present in the entire nucleus. These overall significant effects resulted from an increase in the number of fusiform cells induced by T, DHT, and $\mathrm{DHT}+\mathrm{E}_{2}$, whereas only $\mathrm{T}$ increased the total number of round DCX-ir cells (Fig. 11).

There was no significant effect of steroid hormone treatments on the total number of pyknotic cells in area X (Fig. 11C) $\left(F_{(4,27)}=\right.$ $0.87, p=0.49$ ).

\section{Discussion}

Adult female canaries treated with $\mathrm{T}$ exhibit a remarkable increase in the volume of forebrain song nuclei (Nottebohm, 1980). 

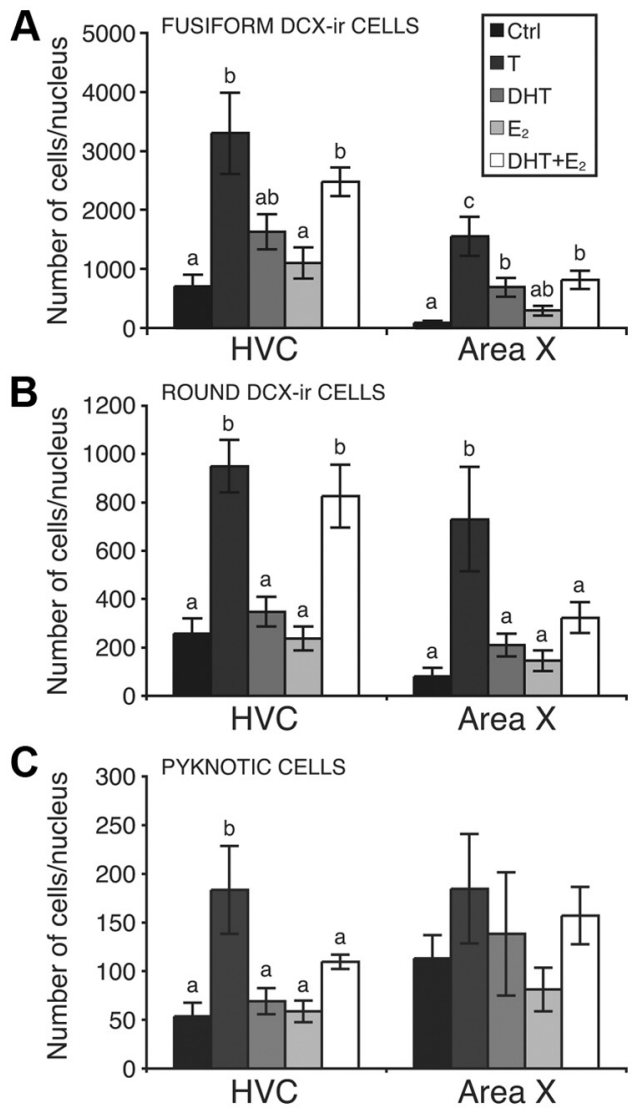

Figure 11. T increased the total numbers of fusiform $(\boldsymbol{A})$ and round $(\boldsymbol{B}) \mathrm{DCX}$-ir cells in HVC and area $X$, as well as the total number of pyknotic cells in HVC only (C). Metabolites of T did not affect total numbers of pyknotic cells, but had region-specific effects on DCX-ir cell numbers, as shown. Letters above bars illustrate significant differences among groups after post hoc tests $(p<0.05)$

Table 1. Summary of changes induced in HVC of female canaries by T, DHT, $E_{2}$, or $\mathrm{DHT}+\mathrm{E}_{2}$ as compared to control birds that had received empty SILASTIC implants

\begin{tabular}{llllc}
\hline Item & $\mathrm{T}$ & DHT & $\mathrm{E}_{2}$ & DHT+E \\
\hline Nuclei volume & + & 0 & 0 & + \\
Neuron density & - & 0 & 0 & - \\
Total neuron number & + & 0 & 0 & + \\
Neuron soma size & + & 0 & 0 & + \\
Fusiform DCX-ir cells/section & + & + & + & + \\
Round DCX-ir cells/section & $0(+)$ & $0(+)$ & 0 & $0(+)$ \\
Pyknotic cells/section & 0 & 0 & 0 & 0 \\
Fusiform DCX-ir cells/HVC & + & 0 & 0 & + \\
Round DCX-ir cells/HVC & + & 0 & 0 & + \\
Pyknotic cells/HVC & + & 0 & 0 & 0 \\
\hline
\end{tabular}

Statistics are indicated versus controls only ( + , increase; - , decrease; 0 , no effect).

Here we demonstrate that both androgenic and estrogenic metabolites of $\mathrm{T}$ are needed to induce these changes and the associated cellular correlates. The key results are summarized in Tables 1 and 2. The interpretation of the data is complex at times as is discussed here.

Effects of androgenic and estrogenic metabolites of $\mathrm{T}$ on song system morphology

Treatment with T increased the volumes of HVC, RA, and area X in intact female canaries as reported previously (Nottebohm, 1980). Administration of DHT or $\mathrm{E}_{2}$ alone did not induce an increase in the volume of song control nuclei, but the combina-
Table 2. Summary of changes induced in area $\mathrm{X}$ of female canaries by $\mathrm{T}, \mathrm{DHT}, \mathrm{E}_{2}$, or $\mathrm{DHT}+\mathrm{E}_{2}$ as compared to control birds that had received empty SILASTIC implants

\begin{tabular}{lcccc}
\hline Item & $\mathrm{T}$ & $\mathrm{DHT}$ & $\mathrm{E}_{2}$ & DHT+E \\
\hline Nuclei volume & + & 0 & 0 & + \\
Neuron density & - & 0 & 0 & - \\
Total neuron number & 0 & 0 & 0 & 0 \\
Neuron soma size & + & 0 & 0 & + \\
Fusiform DCX-ir cells/section & + & + & 0 & + \\
Round DCX-ir cells/section & + & 0 & 0 & 0 \\
Pyknotic cells/section & 0 & 0 & 0 & 0 \\
Fusiform DCX-ir cells/area X & + & + & 0 & + \\
Round DCX-ir cells/area X & + & 0 & 0 & 0 \\
Pyknotic cells/area X & 0 & 0 & 0 & 0 \\
\hline
\end{tabular}

Statistics are indicated versus controls only $(+$, increase; - , decrease; 0 , no effect).

tion $\mathrm{DHT}+\mathrm{E}_{2}$ treatment was effective. These results are consistent with previous studies in canaries on $\mathrm{T}$ metabolites and dendritic growth in RA of adult females (DeVoogd and Nottebohm, 1981) and on HVC volume in males (Sartor et al., 2005). In castrated Gambel's white-crowned sparrows, treatment with DHT or $\mathrm{E}_{2}$ alone induces the growth of song control nuclei, as does treatment with $\mathrm{T}$ or a combination of DHT $+\mathrm{E}_{2}$ (Tramontin et al., 2003). This difference from the current study may be related to species differences or to differences in photoperiod or length of treatment time used in the two studies.

Consistent with previous studies, we found that steroidhormone-induced changes in HVC volume were associated with increases in neuron number and soma size and with decreases in neuron density (Smith et al., 1997; Tramontin et al., 1998) (Fig. 3). In area $\mathrm{X}$, treatments with $\mathrm{T}$ or $\mathrm{DHT}+\mathrm{E}_{2}$ induced an increase in volume, cell density, and neuron soma size, but not in total cell number. These results are similar to a study examining the cellular aspects of seasonal changes in area X volume in male song sparrows (Thompson and Brenowitz, 2005). We also counted pyknotic cells as an indicator of the rate of cell death. As reported previously (Kirn et al., 1994), the numbers we detected were very small, probably because cells are in this state only briefly. We did find that $\mathrm{T}$ increased the number of such cells in HVC, although none of the treatments with $\mathrm{T}$ metabolites were effective. There were no significant effects in area X.

\section{DCX expression}

The DCX protein is expressed widely in the male canary telencephalon, including HVC, area X, and LMAN (Boseret et al., 2007; Balthazart et al., 2008). There are two types of DCX-ir cells, presumably corresponding to migrating neurons (fusiform cells) and to neurons that have recently reached their final destination and begun final differentiation (round cells). The number of DCX-ir cells of each type is increased specifically in HVC of T-treated males compared to castrates (Balthazart et al., 2008). In the current study, all steroid hormone treatments increased the density of DCX-ir fusiform cells in HVC (Fig. 7), but effects of DHT or $\mathrm{E}_{2}$ alone were not statistically significant when considering cell numbers in the entire nucleus (Fig. 11). Different steroid hormone treatments did not affect DCX-ir fusiform (migrating cells) cell numbers in an area lateral to HVC. New neurons in adult songbirds are produced by the division of cells in the lateral ventricle wall (Goldman and Nottebohm, 1983; Alvarez-Buylla and Nottebohm, 1988). These new neurons migrate toward two prominent brain regions, the medial striatum and pallial areas (including HVC), incorporating sparsely into these areas. Some new neurons therefore migrate to and incorporate into HVC, but others pass through HVC and continue to migrate laterally. The 
current study suggests that all the steroid treatments we administered can increase the number of cells migrating to HVC but not necessarily their incorporation: T, DHT, $\mathrm{E}_{2}$, and $\mathrm{DHT}+\mathrm{E}_{2}$ were all effective in increasing the density of fusiform DCX-positive cells into HVC (Fig. 7). However, the results when generalized for the entire nucleus as shown in Figure 11 suggest a more complicated picture. There is also some indication that $\mathrm{T}$ and $\mathrm{E}_{2}+\mathrm{DHT}$ facilitate cell incorporation as reflected by the increased number of round DCX-ir cells (Fig. 11). In any case, there were no significant increases in neuron number or HVC volume in birds administered only DHT or $\mathrm{E}_{2}$. This suggests a general scenario that the increases in DCX-ir cells observed after these treatments (see especially Fig. 7) were due to increased numbers of DCX-ir cells passing through HVC but not actually incorporating into the nucleus.

This scenario must be considered cautiously given the discrepancies observed between measures of cell density per section and cell number per nucleus. For example, there is no significant effect of the combined treatment of $\mathrm{E}_{2}$ and DHT on the density of round cells (Fig. 7), but there is an effect on the total number of cells for the entire HVC (Fig. 11). Such differences could occur because volume increases are due to changes in many aspects of cell morphology (soma size, cell spacing) besides changes in cell numbers, and these effects might have a regional specificity, like the migration of DCX-ir fusiform cells. For example, $\mathrm{E}_{2}$ alone induced a slight decrease in HVC volume (Fig. 2) that may help explain why the density of fusiform DCX-ir cells was increased but not the total number of these cells. It is also useful to note that when extrapolating to the entire nucleus, we multiply the density of cells by volume and thus incorporate two separate measurement errors that may decrease our statistical power. This may explain why DHT increased the density of fusiform DCX-ir cells, but when the total number of cells was considered, there was only a suggestion of an effect (DHT birds are not different from the untreated control but also not different from the T-treated animals).

\section{Conclusion}

The numbers of neurons observed at a given time in a neural structure depend on four possibly independent cellular processes: (1) neurogenesis sensu stricto, i.e., cell divisions of progenitors leading to the birth of new neurons, (2) migration, (3) incorporation into target structures, and (4) survival. Steroids could potentially affect all four processes, but current evidence suggests that they control HVC volume by increasing neuronal incorporation and decreasing neuronal death (e.g., Rasika et al., 1994). In the current study, we investigated the effects of T and its metabolites on these processes. It does not appear that steroid treatment affects cell birth, because increases in DCX-ir cells were observed only in HVC and in an adjacent area passed by new neurons traveling to HVC, not throughout the nidopallium. One would expect that modulation of neuron production at the ventricle would result in widespread changes in DCX-ir cell numbers. Such a pattern was not observed, although we admittedly did not quantify new neurons in the entire telencephalon.

Our DCX quantification suggests a potential dissociation between processes 2 and 3, with 2 being more apt to be regulated by the metabolites of $\mathrm{T}$ in isolation, while 3 would require both. The picture is complicated, however, as all the statistically significant results do not perfectly reflect this scenario. DHT or $\mathrm{E}_{2}$ in isolation appear to direct the migration of new neurons to HVC (increased density of DCX-ir fusiform cells) (Fig. 7), but only treatments with $\mathrm{T}$ or the combined treatment tend to increase the density of incorporated neurons, i.e., round DCX-ir cells (non- significant trends in Fig. 7). However, the combined action $\left(\mathrm{DHT}+\mathrm{E}_{2}\right.$ or $\left.\mathrm{T}\right)$ does result in the recruitment and incorporation of DCX-ir (fusiform and round) cells when measures are based on the entire nucleus (Fig. 11), and this results in an increase in HVC volume (Fig. 3). These results are consistent with previous studies that used T alone (e.g., Brown et al., 1993; Rasika et al., 1994), except that these authors suggested that the rate of cell migration is uniform regardless of steroid treatment, whereas quantification of fusiform DCX-ir cells leads to a different conclusion. An endogenous marker of neurogenesis such as DCX provides an integrated view of all new neurons present at a given time, while BrdU or thymidine provides a snapshot of a population of cells that were born within a few hours after the injection of the tracer (Packard et al., 1973; Miller and Nowakowski, 1988; Böswald et al., 1990). The use of DCX will allow further progress in understanding the mechanisms of neurogenesis, because experiments analyzing the effects of an experimental factor (e.g., steroids) only require taking into account the length of time between exposure to this factor and the time of brain collection. In contrast, investigating at a similar problem with ${ }^{3} \mathrm{H}$-thymidine or BrdU labeling requires a two-factor design considering both the time since injection of thymidine/BrdU and the time since the beginning of treatment.

Steroids are known to act at multiple levels to control song production (Ball et al., 2003). The present study reveals complex effects of androgenic and estrogenic metabolites of $\mathrm{T}$ on various processes underlying the addition of new neurons to HVC and suggests partial dissociations between these endocrine effects. A future challenge will be to identify the sites of action of $\mathrm{T}$ and its metabolites on these semi-independent processes.

\section{References}

Alvarez-Buylla A, Nottebohm F (1988) Migration of young neurons in adult avian brain. Nature 335:353-354.

Alvarez-Buylla A, Kirn JR, Nottebohm F (1990a) Birth of projection neurons in adult avian brain may be related to perceptual or motor learning. Science 249:1444-1446.

Alvarez-Buylla A, Theelen M, Nottebohm F (1990b) Proliferation "hot spots" in adult avian ventricular zone reveal radial cell division. Neuron 5:101-109.

Ball GF, Castelino CB, Maney DL, Appeltants D, Balthazart J (2003) The activation of birdsong by testosterone: multiple sites of action and role of ascending catecholamine projections. Ann NY Acad Sci 1007:211-231.

Balthazart J, Foidart A, Wilson EM, Ball GF (1992) Immunocytochemical localization of androgen receptors in the male songbird and quail brain. J Comp Neurol 317:407-420.

Balthazart J, Boseret G, Konkle AT, Hurley LL, Ball GF (2008) Doublecortin as a marker of adult neuroplasticity in the canary song control nucleus HVC. Eur J Neurosci 27:801-817.

Bernard DJ, Bentley GE, Balthazart J, Turek FW, Ball GF (1999) Androgen receptor, estrogen receptor alpha, and estrogen receptor beta show distinct patterns of expression in forebrain song control nuclei of European starlings. Endocrinology 140:4633-4643

Boseret G, Ball GF, Balthazart J (2007) The microtubule-associated protein doublecortin is broadly expressed in the telencephalon of adult canaries. J Chem Neuroanat 33:140-154.

Böswald M, Harasim S, Maurer-Schultze B (1990) Tracer dose and availability time of thymidine and bromodeoxyuridine: application of bromodeoxyuridine in cell kinetic studies. Cell Tissue Kinet 23:169-181.

Bottjer SW, Halsema KA, Brown SA, Miesner EA (1989) Axonal connections of a forebrain nucleus involved with vocal learning in zebra finches. J Comp Neurol 279:312-326.

Bottjer SW, Brady JD, Cribbs B (2000) Connections of a motor cortical region in zebra finches: relation to pathways for vocal learning. J Comp Neurol 420:244-260.

Brenowitz EA (2008) Plasticity of the song control system in adult birds. In: Neuroscience of birdsong (Zeigler HP, Marler P, eds), pp 332-349. Cambridge: Cambridge UP. 
Brenowitz EA, Lent K (2001) Afferent input is necessary for seasonal growth and maintenance of adult avian song control circuits. J Neurosci 21:2320-2329.

Brenowitz EA, Lent K (2002) Act locally and think globally: intracerebral testosterone implants induce seasonal-like growth of adult avian song control circuits. Proc Natl Acad Sci U S A 99:12421-12426.

Brown JP, Couillard-Després S, Cooper-Kuhn CM, Winkler J, Aigner L, Kuhn HG (2003) Transient expression of doublecortin during adult neurogenesis. J Comp Neurol 467:1-10.

Brown SD, Johnson F, Bottjer SW (1993) Neurogenesis in adult canary telencephalon is independent of gonadal hormone levels. J Neurosci 13:2024-2032.

DeVoogd T, Nottebohm F (1981) Gonadal hormones induce dendritic growth in the adult brain. Science 214:202-204.

Francis F, Koulakoff A, Boucher D, Chafey P, Schaar B, Vinet MC, Friocourt G, McDonnell N, Reiner O, Kahn A, McConnell SK, Berwald-Netter Y, Denoulet P, Chelly J (1999) Doublecortin is a developmentally regulated, microtubule-associated protein expressed in migrating and differentiating neurons. Neuron 23:247-256.

Friocourt G, Koulakoff A, Chafey P, Boucher D, Fauchereau F, Chelly J, Francis F (2003) Doublecortin functions at the extremities of growing neuronal processes. Cereb Cortex 13:620-626.

Gahr M, Güttinger H-R, Kroodsma DE (1993) Estrogen receptors in the avian brain: survey reveals general distribution and forebrain areas unique to songbirds. J Comp Neurol 327:112-122.

Goldman SA, Nottebohm F (1983) Neuronal production, migration, and differentiation in a vocal control nucleus of the adult female canary brain. Proc Natl Acad Sci U S A 80:2390-2394.

Karten HJ, Hodos W (1967) A stereotaxic atlas of the brain of the pigeon (Columba livia). Baltimore: Johns Hopkins.

Kirn J, O'Loughlin B, Kasparian S, Nottebohm F (1994) Cell death and neuronal recruitment in the high vocal center of adult male canaries are temporally related to changes in song. Proc Natl Acad Sci U S A 91:7844-7848.

LaDage LD, Roth TC 2nd, Fox RA, Pravosudov VV (2010) Ecologically relevant spatial memory use modulates hippocampal neurogenesis. Proc $\mathrm{R}$ Soc B 277:1071-1079.

Mello CV, Vates GE, Okuhata S, Nottebohm F (1998) Descending auditory pathways in the adult male zebra finch (Taeniopygia guttata). J Comp Neurol 395:137-160.

Miller MW, Nowakowski RS (1988) Use of bromodeoxyuridine-immunohistochemistry to examine the proliferation, migration and time of origin of cells in the central nervous system. Brain Res 457:44-52.

Nicholls TJ, Goldsmith AR, Dawson A (1988) Photorefractoriness in birds and comparison with mammals. Physiol Rev 68:133-176.

Nottebohm F (1980) Testosterone triggers growth of brain vocal control nuclei in adult female canaries. Brain Res 189:429-436.

Nottebohm F (1981) A brain for all seasons: cyclical anatomical changes in song-control nuclei of the canary brain. Science 214:1368-1370.

Nottebohm F, O'Loughlin B, Gould K, Yohay K, Alvarez-Buylla A (1994) The life span of new neurons in a song control nucleus of the adult canary brain depends on time of year when these cells are born. Proc Natl Acad Sci U S A 91:7849-7853.

Packard DS Jr, Menzies RA, Skalko RG (1973) Incorporation of thymidine and its analogue, bromodeoxyuridine, into embryos and maternal tissues of the mouse. Differentiation 1:397-404.

Rao MS, Shetty AK (2004) Efficacy of doublecortin as a marker to analyse the absolute number and dendritic growth of newly generated neurons in the adult dentate gyrus. Eur J Neurosci 19:234-246.

Rasika S, Nottebohm F, Alvarez-Buylla A (1994) Testosterone increases the recruitment and/or survival of new high vocal center neurons in adult female canaries. Proc Natl Acad Sci U S A 91:7854-7858.

Reiner A, Perkel DJ, Bruce LL, Butler AB, Csillag A, Kuenzel W, Medina L, Paxinos G, Shimizu T, Striedter G, Wild M, Ball GF, Durand S, Güntürkün O, Lee DW, Mello CV, Powers A, White SA, Hough G, Kubikova L, et al. (2004) Revised nomenclature for avian telencephalon and some related brainstem nuclei. J Comp Neurol 473:377-414.

Sartor JJ, Ball GF (2005) Social suppression of song is associated with a reduction in volume of a song-control nucleus in European starlings (Sturnus vulgaris). Behav Neurosci 119:233-244.

Sartor JJ, Balthazart J, Ball GF (2005) Coordinated and dissociated effects of testosterone on singing behavior and song control nuclei in canaries ( $\mathrm{Se}$ rinus canaria). Horm Behav 47:467-476.

Schlinger BA, Brenowitz EA (2002) Neural and hormonal control of birdsong. In: Hormones, brain and behavior (Pfaff DW, Arnold AP, Etgen AM, Fahrbach SE, Rubin RT, eds), pp 799-839. San Diego: Academic.

Smith GT, Brenowitz EA, Wingfield JC, Baptista LF (1995) Seasonal changes in song nuclei and song behavior in Gambels white-crowned sparrows. J Neurobiol 28:114-125.

Smith GT, Brenowitz EA, Beecher MD, Wingfield JC (1997) Seasonal changes in testosterone, neural attributes of song control nuclei, and song structure in wild songbirds. J Neurosci 17:6001-6010.

Soma KK, Hartman VN, Wingfield JC, Brenowitz EA (1999) Seasonal changes in androgen receptor immunoreactivity in the song nucleus $\mathrm{HVc}$ of a wild bird. J Comp Neurol 409:224-236.

Stokes TM, Leonard CM, Nottebohm F (1974) The telencephalon, diencephalon, and mesencephalon of the canary, Serinus canaria, in stereotaxic coordinates. J Comp Neurol 156:337-374.

Thompson CK, Brenowitz EA (2005) Seasonal change in neuron size and spacing but not neuronal recruitment in a basal ganglia nucleus in the avian song control system. J Comp Neurol 481:276-283.

Tramontin AD, Smith GT, Breuner CW, Brenowitz EA (1998) Seasonal plasticity and sexual dimorphism in the avian song control system: stereological measurement of neuron density and number. J Comp Neurol 396:186-192.

Tramontin AD, Wingfield JC, Brenowitz EA (2003) Androgens and estrogens induce seasonal-like growth of song nuclei in the adult songbird brain. J Neurobiol 57:130-140.

Vates GE, Broome BM, Mello CV, Nottebohm F (1996) Auditory pathways of caudal telencephalon and their relation to the song system of adult male zebra finches (Taenopygia guttata). J Comp Neurol 366:613-642. 